\title{
Quantum efficiency and temperature coefficients of GalnP/GaAs dual-junction solar cell
}

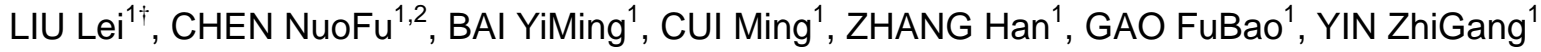 \\ \& ZHANG XingWang ${ }^{1}$ \\ ${ }^{1}$ Key Laboratory of Semiconductor Materials Science, Institute of Semiconductors, Chinese Academy of Sciences, POB 912, Beijing \\ 100083, China; \\ ${ }^{2}$ National Laboratory of Microgravity, Institute of Mechanics, Chinese Academy of Sciences, Beijing 100080, China
}

GalnP/GaAs dual-junction solar cell with a conversion efficiency of $25.2 \%$ has been fabricated using metalorganic chemical vapor deposition (MOCVD) technique. Quantum efficiencies of the solar cell were measured within a temperature range from 25 to $160^{\circ} \mathrm{C}$. The results indicate that the quantum efficiencies of the subcells increase slightly with the increasing temperature. And red-shift phenomena of absorption limit for all subcells are observed by increasing the cell's work temperature, which are consistent with the viewpoint of energy gap narrowing effect. The short-circuit current density temperature coefficients $d J_{s c} / d T$ of GalnP subcell and GaAs subcell are determined to be 8.9 and 7.4 $\mu \mathrm{A} / \mathrm{cm}^{2} I^{\circ} \mathrm{C}$ from the quantum efficiency data, respectively. And the open-circuit cell voltage temperature coefficients $\mathrm{d} V_{\mathrm{oc}} / \mathrm{d} T$ calculated based on a theoretical equation are $-2.4 \mathrm{mV} /{ }^{\circ} \mathrm{C}$ and $-2.1 \mathrm{mV} /^{\circ} \mathrm{C}$ for $\mathrm{GalnP}$ subcell and GaAs subcell.

quantum efficiency, temperature coefficient, solar cell

\section{Introduction}

Tandem solar cell with concentrator system has attracted great interest and has been extensively studied in the recent years due to its high conversion efficiency and comparatively low cost ${ }^{[1-3]}$. It is known that concentrated light could increase the conversion efficiency of solar cells at an appropriate concentration ratio because the short-circuit current density $J_{\text {sc }}$ and open-circuit cell voltage $V_{\text {oc }}$ increase linearly and logarithmically with the increasing light intensity, respectively. Accompanied with increasing concentration levels is also a potential rise in solar cell temperature, which is an undesirable effect since it reduces cell efficiency. Therefore, a deep understanding of device temperature coefficient is vital for a concentrator system.

Earlier studies ${ }^{[4]}$ had pointed out that the performance of solar cells decreased with an increase of temperature. Fan theoretically calculated the temperature dependence of the parameters of GaAs, Si and Ge single junction solar cells ${ }^{[5]}$. The temperature coefficients of GaInP/ GaAs dual-junction solar cell were theoretically calculated by Friedman ${ }^{[6]}$. But their works were limited in a relatively narrow temperature range $\left(25-100^{\circ} \mathrm{C}\right)$. In this paper, GaAs single-junction and GaInP/GaAs dual-junction solar cells are fabricated. The quantum efficiencies of the solar cells are measured within the temperature range from 25 to $160^{\circ} \mathrm{C}$. The $J_{\text {sc }}$ of the GaInP/GaAs dual-junction solar cell is calculated at different temperatures using the measurement quantum efficiency data. The temperature coefficients of short-circuit current and open-circuit cell voltage of the solar cells are also discussed.

\section{Experiment}

GaInP/GaAs dual-junction solar cell and GaAs single-

Received October 8, 2007; accepted March 4, 2008; published online October 23, 2008 doi: 10.1007/s11431-008-0203-9

${ }^{\dagger}$ Corresponding author (email: $\underline{\text { lliu@semi.ac.cn) }}$ 
junction solar cell for this study were grown on n-type Ge substrates using metalorganic chemical vapor deposition (MOCVD) technique. The main precursors used to form the lattice layers were rimethylgallium (TMGa), trimethylindium (TMIn), trimethylaluminum (TMAl), arsine and phosphine. The dophants sources are hydrogen selenide $\left(\mathrm{H}_{2} \mathrm{Se}\right)$ and diethylzinc (DEC). Before epitaxial growth the Ge substrate was prebaked at $700^{\circ} \mathrm{C}$ at hydrogen atmosphere for $10 \mathrm{~min}$. And then $\mathrm{AsH}_{3}$ was introduced to growing GaAs buffer layer at a temperature range of $400-450^{\circ} \mathrm{C}$. The n-type GaAs BSF layer, n-type GaAs base layer, p-type GaAs emitter layer and the AlGaAs window layer of the GaAs subcell were orderly grown at $600^{\circ} \mathrm{C}$. The growth temperatures were $550^{\circ} \mathrm{C}$ and $600^{\circ} \mathrm{C}$ for p-type and n-type GaAs layers of tunnel junction, respectively. The base layer and emitter layer of GaInP subcell were grown at $650^{\circ} \mathrm{C}$, and AlInP BSF layer and window layer were grown at $680^{\circ} \mathrm{C}$. The growth process of GaAs cap layer was similar to that of GaAs subcell. Figure 1 shows the schematic illustration of the InGaP/GaAs dual-junction cell fabricated in this study. The structure of GaAs single-junction solar cells is similar to that of GaAs subcell of the $\mathrm{InGaP} / \mathrm{GaAs}$ dual-junction solar cell.

\begin{tabular}{l} 
MF2/ZnSARC \\
\hline p-AlInP window $0.02 \mu \mathrm{m}$ \\
\hline $\mathrm{p}$-GaInP emitter $0.1 \mu \mathrm{m}$ \\
\hline $\mathrm{n}$-GaInP base $0.7 \mu \mathrm{m}$ \\
\hline $\mathrm{n}$-AlInP BSF $0.05 \mu \mathrm{m}$ \\
\hline $\mathrm{p}$-GaAs/p-GaAs TJ $0.03 \mu \mathrm{m}$ \\
\hline $\mathrm{p}-\mathrm{AlGaAs}$ window $0.03 \mu \mathrm{m}$ \\
\hline $\mathrm{p}$-GaAs emitter $0.1 \mu \mathrm{m}$ \\
\hline $\mathrm{n}$-GaAs base $3.5 \mu \mathrm{m}$ \\
\hline $\mathrm{n}$-GaAs BSF $0.2 \mu \mathrm{m}$ \\
\hline $\mathrm{n}$-GaAs buffer $0.2 \mu \mathrm{m}$ \\
\hline $\mathrm{n}$-Ge base $350 \mu \mathrm{m}$ \\
\hline
\end{tabular}

Figure 1 Schematic illustration of GaInP/GaAs dual-junction solar cell.

$\mathrm{J}-\mathrm{V}$ characters of the GaInP/GaAs dual-junction solar cell and GaAs single-junction solar cell (5 $\mathrm{mm} \times 5 \mathrm{~mm})$ were measured under the standard spectrum of AM1.5 at $25^{\circ} \mathrm{C}$. The measurements of sample's quantum efficiencies were all performed with temperature variation from 25 to $160^{\circ} \mathrm{C}$. In the process of spectral response measurement the sample was first mounted on a copper block, which was also a heater used to elevate the sample temperature, and the Pt-100 temperature sensor was used to measure the temperature. Monochromatic light modulated by mechanical chopper at $f=22 \mathrm{~Hz}$ was used in spectral measurements. Additionally, a three-channel light source which could provide monochromatic lights (460, 820 and $1090 \mathrm{~nm}$ ) was used as bias light when a subcell was under tested. Evaluation of the quantum efficiency in absolute units was carried out by comparison of the photocurrent magnitudes from a calibrated reference cell and the solar cells under test at monochromatic illumination.

\section{Theoretical investigation}

One of the requirements for a high efficiency multijunction solar cell is the current matching of the subcells. But for a multijunction solar cell it is impossible to get the short-circuit current of each subcell directly from the $\mathrm{J}-\mathrm{V}$ curve measurement. Because the $J_{\mathrm{sc}}$ of a multijunction solar cell is always determined by a subcell that has the lowest current output of all the subcells. Fortunately, spectral response measurement can provide the quantum efficiency data of each subcell to calculate the $J_{\text {sc }}$. So quantum efficiency is very helpful for the study of solar cells, especially for the multijunction solar cells. The quantum efficiency at a given wavelength $\lambda$ is defined as

$$
Q E(\lambda)=\frac{J_{\mathrm{sc}}(\lambda)}{q \phi(\lambda)}
$$

where $J_{\mathrm{sc}}(\lambda)$ is the total photogenerated short-circuit current density at a given wavelength $\lambda, \varphi(\lambda)$ is the photon flux of the corresponding incident light and $q$ is the elementary charge $\mathrm{in]}^{[7]}$. So the $J_{\mathrm{sc}}$ of a solar cell under a certain spectrum can be given by

$$
J_{\text {sc }}=\int_{\lambda_{1}}^{\lambda_{2}} q \phi(\lambda) Q E(\lambda) \mathrm{d} \lambda .
$$

If the quantum efficiency of a solar cell is measured at a given temperature, and the $\varphi(\lambda)$ is the photon flux of the standard spectrum of AM1.5, we can calculate the $J_{\mathrm{sc}}$ of the solar cell at the given temperature based on eq. (2). Then the temperature coefficient of short-circuit current density can be evaluated from the change of $J_{\mathrm{sc}}$.

\section{Results and discussions}

Figure 2 shows the measured $\mathrm{J}-\mathrm{V}$ characteristics of the $\mathrm{GaInP} / \mathrm{GaAs}$ dual-junction solar cell and GaAs single 
junction solar cell under AM1.5 at $25^{\circ} \mathrm{C}$. Table 1 presents the output parameters for the solar cells. It is clear from Table 1 that the conversion efficiency of GaInP/ GaAs solar cell is better than that of single GaAs solar cell. Though the measured conversion efficiency for GaInP/GaAs dual-junction solar cell reaches $25.2 \%$ in our experiment, it is still lower than the best published efficiency ${ }^{[8]}$. This is mainly due to the comparatively low short-circuit current density $J_{\mathrm{sc}}$ and the $V_{\text {oc }}$ of the cell. It has been mentioned above that the $J_{\text {sc }}$ of a multijunction solar cell is determined by the subcell that has the lowest current output of all the subcells. Therefore quantum efficiencies of GaInP/GaAs dual-junction solar cell were measured in order to get the $J_{\mathrm{sc}}$ of each subcell.

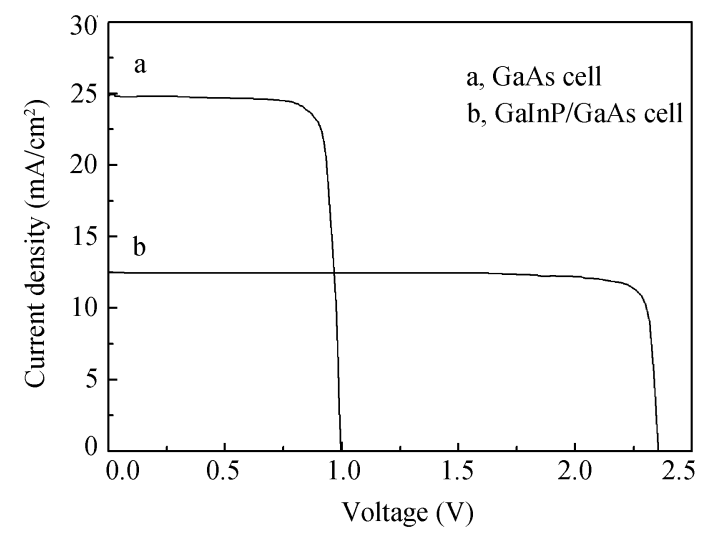

Figure 2 J-V characteristics for GaInP/GaAs dual-junction solar cell and GaAs single-junciton solar cell.

Table 1 Output parameters for the GaInP/GaAs dual-junction solar cell and GaAs single-junciton solar cell

\begin{tabular}{ccc}
\hline Cell parameter & GaAs & GaInP/GaAs \\
\hline$J_{\mathrm{sc}}\left(\mathrm{mA} / \mathrm{cm}^{2}\right)$ & 24.9 & 12.5 \\
$V_{\mathrm{oc}}(\mathrm{V})$ & 1 & 2.37 \\
$F F$ & 0.82 & 0.85 \\
Efficiency (\%) & 20.4 & 25.2 \\
\hline
\end{tabular}

Figure 3 shows the quantum efficiencies of the $\mathrm{GaInP} / \mathrm{GaAs}$ dual-junction solar cell at $25^{\circ} \mathrm{C}$. The photon flux curve of AM1.5 standard spectrum is also presented as a dashed line. One can see from Figure 3 that the quantum efficiency of GaInP subcell reaches a maximum value of $89 \%$ at $0.5 \mu \mathrm{m}$ and then decreases with increasing wavelength. GaAs subcell's quantum efficiency keeps at a high level of above $92 \%$ in the range of $0.71-0.86 \mu \mathrm{m}$. By taking into account the measured quantum efficiencies of each subcell and the photon flux of AM1.5 standard spectrum, the $J_{\mathrm{sc}}$ of

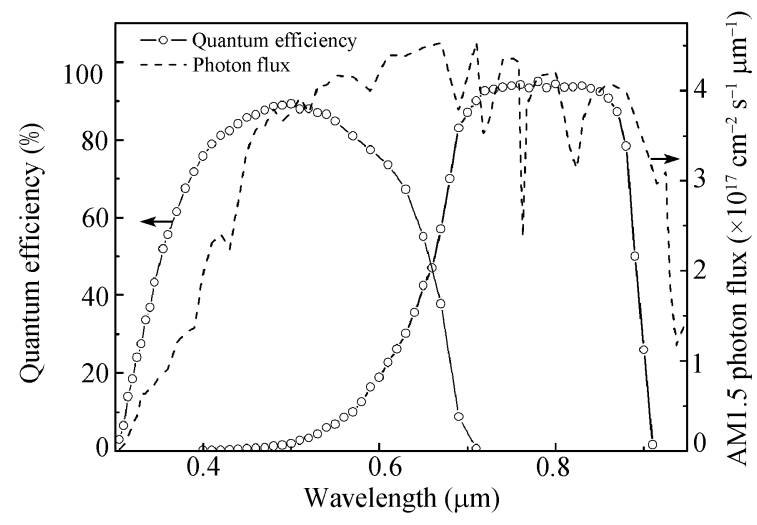

Figure 3 Quantum efficiency of GaInP/GaAs dual-junction solar cell at $25^{\circ} \mathrm{C}$ and the photon flux curve of AM1.5 standard spectrum.

GaInP and GaAs subcells can be calculated based on eq. (2). The calculated $J_{\text {sc }}$ 's of GaInP and GaAs subcells are $12.9 \mathrm{~mA} / \mathrm{cm}^{2}$ and $13.4 \mathrm{~mA} / \mathrm{cm}^{2}$, respectively. This result clearly indicates that the $J_{\mathrm{sc}}$ of the $\mathrm{GaInP} / \mathrm{GaAs}$ dual-junction solar cell is limited by the GaInP top cell at room temperature. Since it is limited by GaInP top cell the calculated $J_{\mathrm{sc}}$ based on quantum efficiency for the $\mathrm{GaInP} / \mathrm{GaAs}$ dual-junction solar cell should be 12.9 $\mathrm{mA} / \mathrm{cm}^{2}$, which is a little higher than the measured 12.5 $\mathrm{mA} / \mathrm{cm}^{2}$. Therefore, the performance of GaInP subcell is a key factor for a high conversion efficiency of $\mathrm{GaInP/GaAs} \mathrm{dual-junction} \mathrm{solar} \mathrm{cell.} \mathrm{And} \mathrm{a} \mathrm{great} \mathrm{effort}$ should be made to optimize the cell structure and the fabrication technology especially for GaInP subcell.

The quantum efficiencies of the GaInP/GaAs dualjunction solar cell at different temperatures are shown in Figure 4. Red-shift phenomena of absorption limit for all subcells are observed by increasing the cell's work temperature, which are consistent with the viewpoint of energy gap narrowing effect. Additionally, the quantum efficiencies exhibit a slight improvement with the elevated temperature, which was also reported by Feteha ${ }^{[9]}$. It is considered that the increased diffusion length for minority carriers with temperature is responsible for the improvement of quantum efficiencies.

The $J_{\text {sc }}$ 's of each subcell of the $\mathrm{GaInP} / \mathrm{GaAs}$ cell at different temperatures have been calculated using eq. (2). The temperature dependence of $J_{\mathrm{sc}}$ for each subcell of $\mathrm{GaInP} / \mathrm{GaAs}$ sorlar cell is presented in Figure 5. It is known from Figure 5 that the $J_{\mathrm{sc}}$ increases linearly with increasing temperature. The $J_{\mathrm{sc}}$ temperature coefficients for GaInP and GaAs subcell are determined to be 8.9 and $7.4 \mu \mathrm{A} / \mathrm{cm}^{2} /{ }^{\circ} \mathrm{C}$, respectively. The $J_{\text {sc }}$ of GaInP top cell 


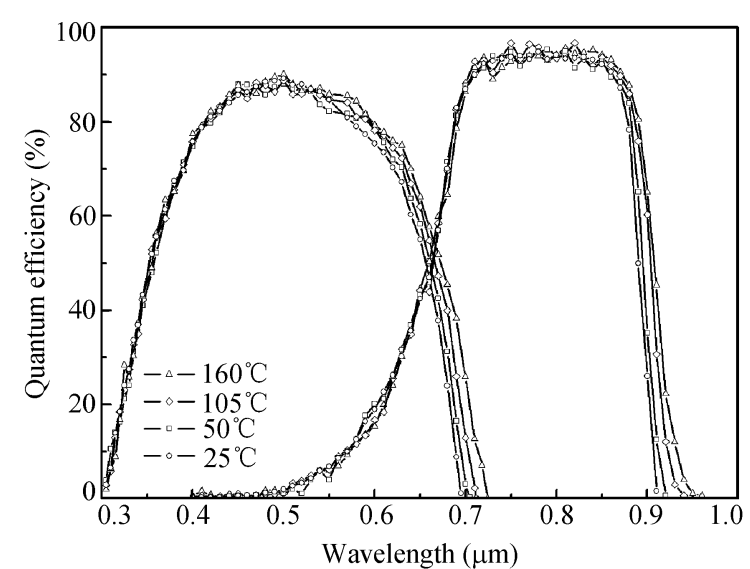

Figure 4 Quantum efficiencies of GaInP and GaAs subcells at different temperatures.

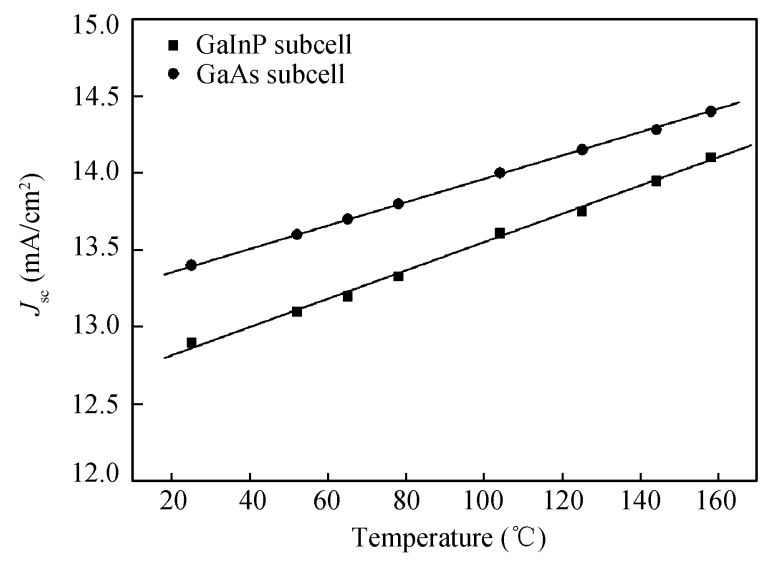

Figure 5 Calculated short-circuit currents densities $J_{\text {sc }}$ of GaInP and GaAs subcells at different temperatures.

reaches $14.1 \mathrm{~mA} / \mathrm{cm}^{2}$ at $160^{\circ} \mathrm{C}$, which is still lower than that of GaAs bottom cell of $14.4 \mathrm{~mA} / \mathrm{cm}^{2}$. This suggests that the $J_{\mathrm{sc}}$ of the GaInP/GaAs dual-junction solar cell is still limited by the GaInP top cell untill $160^{\circ} \mathrm{C}$. In ref. [7], Friedman suggested that the $J_{\mathrm{sc}}$ of the GaInP/GaAs solar cell becomes GaAs-subcell-limited when temperature reaches about $75^{\circ} \mathrm{C}$. It must be pointed out that Friedman's calculation was based on the assumption that the spectral response was determined only by the cell absorption coefficients, which tends to overevaluate the $J_{\text {sc }}$. On the other hand, for the GaInP top cell with a higher $J_{\text {sc }}$ the transition from GaInP-subcell-limited to
GaAs-subcell-limited may appear at a relatively low temperature.

The temperature will have an effect on not only the $J_{\text {sc }}$ but also $V_{\text {oc }}$. The increasing temperature would induce a significant drop of $V_{\text {oc }}$ for a solar cell. Though the temperature coefficients of $V_{\text {oc }}$ of a solar cell can be directly measured, there is still another way for us to discuss the temperature coefficients of $V_{\mathrm{oc}}$. Generally, the $V_{\text {oc }}$ can be described by

$$
V_{\mathrm{oc}}=\frac{n k T}{q} \ln \left(\frac{J_{\mathrm{sc}}}{J_{\mathrm{o}}}+1\right),
$$

where $J_{0}, n, k$ and $T$ are the dark saturation current density, diode ideality factor, Boltzmann constant, and absolute temperature, respectively. Assume the dark saturation current density $J_{0}$ of a single junction can be described by

$$
J_{\mathrm{o}}=\text { const } \times T^{3 / n} \exp \left(\frac{-E_{g}}{k T}\right) .
$$

From eqs. (3) and (4), it is considered that the temperature characteristic of $V_{\text {oc }}$ is remarkably influenced by $J_{0}$. Setting $n=1, \mathrm{~d} V_{\mathrm{oc}} / \mathrm{d} T$ can be given by

$$
\frac{\mathrm{d} V_{\mathrm{oc}}}{\mathrm{d} T}=\frac{1}{T}\left[V_{\mathrm{oc}}-\frac{E_{\mathrm{g}}}{q}-\frac{3 k T}{q}\right]+\frac{1}{q} \frac{\mathrm{d} E_{g}}{\mathrm{~d} T}+\frac{k T}{q J_{\mathrm{sc}}} \frac{\mathrm{d} J_{\mathrm{sc}}}{\mathrm{d} T} .
$$

More details about the deduction can be found in ref. [7]. For the given values of $V_{\text {oc }}, \mathrm{d} E_{\mathrm{g}} / \mathrm{d} T$ and $\mathrm{d} J_{\mathrm{sc}} / \mathrm{d} T$ one can calculate the $\mathrm{d} V_{\text {oc }} / \mathrm{d} T$ of a subcell according to eq. (5). If the $V_{\text {ocb }}$ of GaAs bottom cell could take that of the GaAs single-junction cell, then the $V_{\text {oct }}$ of GaInP top cell will be $V_{\text {oct }}=V_{\text {octandem }}-V_{\text {ocb }}=1.37 \mathrm{~V}$. And the $\mathrm{d} E_{g} / \mathrm{d} T$ can be calculated according to the equation $E_{\mathrm{g}}(T)=E_{\mathrm{g}}(0)-$ $\alpha T^{2} /(T+\beta)$. Table 2 presents the related parameters for the subcells.

The temperature coefficients of $V_{\text {oc }}$ calculated based on eq. (5) for GaInP subcell and GaAs subcell are -2.4 $\mathrm{mV} /{ }^{\circ} \mathrm{C}$ and $-2.1 \mathrm{mV} /{ }^{\circ} \mathrm{C}$, respectively, which are very close to the published data $\left(-2.5 \mathrm{mV} /{ }^{\circ} \mathrm{C}\right.$ and -2.2 $\left.\mathrm{mV} /{ }^{\circ} \mathrm{C}\right)^{[9]}$. It is considered that the $V_{\text {oc }}$ of a multijunction solar cell is the sum of the subcells. So the $V_{\text {oc }}$ temperature

Table 2 Short-circuit current densities $J_{\mathrm{sc}}$, open-circuit voltages $V_{\mathrm{oc}}$, energy gaps $E_{\mathrm{g}}$, and corresponding temperature parameters of GaInP and GaAs subcells

\begin{tabular}{ccccccccc}
\hline & $E_{\mathrm{g}}(\mathrm{eV})$ & $\alpha^{[10]}$ & $\beta^{[10]}$ & $\mathrm{d} E_{\mathrm{g}} / \mathrm{d} T\left(\mathrm{meV} /{ }^{\circ} \mathrm{C}\right)$ & $J_{\mathrm{sc}}\left(\mathrm{mA} / \mathrm{cm}^{2}\right)$ & $\mathrm{d} J_{\mathrm{sc}} / \mathrm{d} T\left(\mu \mathrm{A} / \mathrm{cm}^{2} /{ }^{\circ} \mathrm{C}\right)$ & $V_{\mathrm{oc}}(\mathrm{V})$ & $\mathrm{d} V_{\mathrm{oc}} / \mathrm{d} T\left(\mathrm{mV} /{ }^{\circ} \mathrm{C}\right)$ \\
\hline GaInP & 1.86 & $6.1 \times 10^{-4}$ & 204 & -0.51 & 12.9 & 8.9 & 1.37 & -2.4 \\
$\mathrm{GaAs}$ & 1.42 & $5.4 \times 10^{-4}$ & 204 & -0.45 & 13.4 & 7.4 & 1 & -2.1 \\
\hline
\end{tabular}


coefficient $\mathrm{d} V_{\text {oc }} / \mathrm{d} T$ of a multijunction solar cell is simply the sum of the temperature coefficients of the subcells. It means that the open-circuit cell voltage of the GaInP/GaAs dual-junction solar cell will drop to about $1.76 \mathrm{~V}$ when the temperature reaches $160^{\circ} \mathrm{C}$ with an open-circuit cell voltage temperature coefficient of -4.5 $\mathrm{mV} /{ }^{\circ} \mathrm{C}$. So the performance of a cell is strongly influenced by the open-circuit cell voltage $V_{\text {oc }}$.

\section{Conclusions}

GaInP/GaAs dual-junction solar cell and GaAs single-junction solar cell have been fabricated using MOCVD growth method. A conversion efficiency of 25.2\% for GaInP/GaAs dual-junction solar cell was achieved in our experiment. The short-circuit current densities $J_{\mathrm{sc}}$ of the subcells were calculated based on the quantum efficiency data measured in the temperature range of 25 to $160^{\circ} \mathrm{C}$. And the results indicate that the $J_{\mathrm{sc}}$ of the GaInP/GaAs dual-junction solar cell is limited by the GaInP top cell in the whole temperature range of our study. The $J_{\text {sc }}$ temperature coefficients $\mathrm{d} J_{\mathrm{sc}} / \mathrm{d} T$ of GaInP subcell and GaAs subcell are determined to be 8.9 and $7.4 \mu \mathrm{A} / \mathrm{cm}^{2} /{ }^{\circ} \mathrm{C}$, respectively. And the $V_{\text {oc }}$ temperature coefficients $\mathrm{d} V_{\mathrm{oc}} / \mathrm{d} T$ calculated based on a theoretical equation are $-2.4 \mathrm{mV} /{ }^{\circ} \mathrm{C}$ and $-2.1 \mathrm{mV} /{ }^{\circ} \mathrm{C}$ for $\mathrm{GaInP}$ subcell and GaAs subcell, respectively.

1 Friedman D J, Kurtz S R, Bertness K A, et al. Accelerated publication -30.2-percent efficient GaInP/GaAs monolithic 2-terminal tandem concentrator cell. Prog Photovoltaics, 1995, 3 (1): 47-50[DOI]

2 Yamaguchi M. III-V compound multi-junction solar cells: present and future. Sol Energy Mater Sol Cells, 2003, 75(1-2): 261-269[DOI]

3 Dimroth F, Beckert R, Meusel M, et al. Metamorphic $\mathrm{Ga}_{y} \mathrm{In}_{1-y} \mathrm{P} /$ $\mathrm{Ga}_{1-x} \mathrm{In}_{x}$ As tandem solar cells for space and for terrestrial concentrator applications at C > 1000 suns. Prog Photovoltaics, 2001, 9 (3): 165$178[\mathrm{DOI}]$

4 Wysocki J J, Rappaport P. Effect of temperature on photovoltaic solar energy conversion. J Appl Phys, 1960, 31(3): 571 - 578[DOI]

5 Fan C C J. Theoretical temperature dependence of solar cell parameters. Sol Cells, 1986, 17(2-3): 309-315[DOI]

6 Friedman D J. Modelling of tandem cell temperature coefficients. IEEE 25th PV Spec Conf. 13-17, May, 1996, 89-92

7 Ai B, Sheng $H$, Ban Q, et al. QE and Suns- $V_{\text {oc }}$ study on the epitaxial CSiTF solar cells. Sci China Ser E-Tech Sci, 2005, 48(1): 41-52[DOI]

8 Green M A, Emery K, King D L, et al. Solar cell efficiency tables. Prog Photovoltaics, 2007, 15(1): 35-40 [DOI]

9 Feteha M Y, Eldallal G M. The effects of temperature and light concentration on the GaInP/GaAs multijunction solar cell's performance. Renewable Energy, 2003, 28(7): 1097-1104[DOI]

10 Levinshtein M, Rumyantsev S. Handbook Series on Semiconductor Parameters. Singapore: World Scientific, 1996. 33-102 